\title{
PENGUKURAN KONSENTRASI LARUTAN SODIUM HIDROKSIDA (NaOH) DENGAN TRANSDUSER KAPASITIF
}

\author{
Muhammad Hidayatullah $^{1 *}$, Kuwat Triyana ${ }^{2}$ \\ J'Program Studi Teknik Elektro, FTI, Universitas Teknologi Sumbawa. \\ ${ }^{2}$ Jurusan Fisika, FMIPA, Universitas Gadjah Mada,Yogyakarta \\ *Korespondensi ke: mhhidayat07@gmail.com \\ ( Diterima:29 Januari 2018; Direvisi: 15 Februari 2018; Diterbitkan: 01 Maret 2018 )
}

\begin{abstract}
ABSTRAK
Telah dilakukan pengukuran konsentrasi larutan sodium hidroksida $(\mathrm{NaOH})$ menggunakan transduser kapasitif yang bekerja berdasarkan fenomena electrical capacitive tomography (ECT). Sebelum digunakan, transduser kapasitif diverifikasi berdasarkan ASTM D.1076-02 terhadap sampel larutan getah lateks oleh Laboratorium Penguji Balai Penelitian Teknologi Karet Bogor. Jenis larutan yang diukur konsentrasinya dalam penelitian ini adalah larutan sodium hidroksida $(\mathrm{NaOH})$ dengan pelarut air pada berbagai variasi konsentrasi. Larutan $\mathrm{NaOH}$ mewakili bahan elektrolit. Dalam pelaksanaan pengukuran konsentrasi larutan, dibutuhkan konsentrasi tertinggi sebagai referensi yang dalam hal ini larutan $\mathrm{NaOH}$ dengan konsentrasi $80 \%$, sehingga dari grafik hasil pengukuran diperoleh nilai koefisien korelasi sebesar 0,999. Dengan demikian dapat disimpulkan bahwa transduser kapasitif mempunyai potensi yang tinggi sebagai alat alternatif untuk mengukur konsentrasi larutan dengan cepat tanpa preparasi sampel.

Kata kunci: transduser kapasitif, electrical capacitive tomography, konsentrasi larutan.
\end{abstract}

\begin{abstract}
Sodium hydroxide solution (NaOH) concentration has been measured using capacitive transducers that work based on electrical capacitive tomography (ECT) phenomenon. Prior to use, a capacitive transducer was verified based on ASTM D.1076-02 on a latex latex solution sample by the Rubber Technology Research Laboratory of Bogor Technology Research Institute. The type of solution measured by concentration in this study is a solution of sodium hydroxide $(\mathrm{NaOH})$ with water solvent in various concentration variations. The $\mathrm{NaOH}$ solution represents the electrolyte material. In the measurement of solution concentration, the highest concentration is needed as a reference in this case $\mathrm{NaOH}$ solution with $80 \%$ concentration, so from the measurement result graph obtained correlation coefficient value of 0.999. Thus it can be concluded that the capacitive transducer has a high potential as an alternative tool to measure the concentration of the solution quickly without sample preparation.
\end{abstract}

Keywords: capacitive transducers, electrical capacitive tomography, concentration of solution 


\section{PENDAHULUAN}

Bahan dielektrik dapat diartikan suatu bahan yang memiliki daya hantar arus yang sangat kecil atau bahkan hampir tidak ada. Bahan dielektrik ini dapat berwujud padat, cair dan gas. Ketika bahan ini berada dalam medan listrik, muatan listrik yang terkandung di dalamnya tidak mengalami pergerakan sehingga tidak akan timbul arus seperti bahan konduktor ataupun semikonduktor, tetapi hanya sedikit bergeser dari posisi setimbangnya yang mengakibatkan terciptanya pengutuban dielektrik (Utomo dkk, 2011). Bahan dielektrik ada dua jenis, yakni polar dan non-polar. Molekul dielektrik polar berarti bahwa molekul dielektrik tersebut ketika dalam keadaan tanpa medan listrik, antara elektron dan intinya telah membentuk dipol. Sedangkan molekul non-polar ketika tidak ada medan listrik antara elektron dan inti tidak tampak sebagai dua muatan terpisah. Dielektrik molekul polar maupun non polar bila diletakkan dalam medan listrik akan mengalami polarisasi (Sehah dkk, 2009). Setiap bahan isolator mempunyai sifat dielektrik yang berbeda-beda. Bahan dengan sifat dielektrik yang cukup baik, banyak dimanfaatkan sebagai bahan baku pada industri terutama industri elektronik dan bangunan (Eryolamda dan Reny, 2010).

Kemudian metode pengukuran konsentrasi bahan yaitu konsentrasi atau kadar karet kering menggunakan photoelectric sensor yang terdiri dari sensor fotolistrik (photoelectric sensor), laser diode, detektor jarak, two-stage amplifier modul, pengkonversi sinyal, mikroprosesor dan sebagainya. Metode ini mengikuti prinsip Lambert, dimana reflektivitas sampel akan berbeda ketika kandungan sampel karet kering berbeda (Rejikumar dan J.Philip, 2010). Selain metode tersebut, dikembangkan juga metode pengukuran yang berbasis sensor atau transduser. Salah satu jenis transduser yang dikembangkan adalah transduser kapasitif yang bekerja berdasarkan fenomena Electrical Capacitance Tomography (ECT). Tomography adalah proses visualisasi gambar dua dimensi maupun tiga dimensi yang banyak digunakan dalam proses industri. Electrical capacitance tomography (ECT) merupakan salah satu proses dalam tomography. ECT terdiri dari tiga bagian utama yaitu sensor, sinyal kondisioning, dan komputer. Sensor terbuat dari plat tembaga yang berfungsi sebagai elektroda untuk mengukur perubahan kapasitansi, sinyal kondisioning berupa rangkaian elektronik yang mengkonversi sinyal dari elektroda menjadi data digital, sedangkan komputer berfungsi sebagai pengolah data dan rekonstruksi image menjadi gambar dua dimensi atau tiga dimensi (Horng dkk, 2003).

Sehingga dari fenomena tersebut dengan memanfaatkan perubahan kapasitansi dari suatu bahan uji yakni hasil pembacaannya berupa data tegangan dan konsentrasi larutan bahan digunakan sebagai dasar dalam penelitian ini, dimana transduser kapasitif digunakan untuk pengukuran konsentrasi larutan $\mathrm{NaOH}$ yang merupakan basa kuat (kaustik) dengan sifat elektrolitnya. Hasil akhirnya dapat dilihat perbedaan respon transduser kapasitif dalam pengukuran konsentrasi larutan non-elektrolit serta untuk menguji performa transduser kapasitif dari aspek metrologinya. 


\section{METODE PENELITIAN}

Pengukuran konsentrasi larutan sodium hidroksida $(\mathrm{NaOH})$ dengan pelarut air menggunakan transduser kapasitif dilakukan di laboratorium Laboratorium Fisika Material \& Instrumentasi Fakultas MIPA UGM. Sebelum digunakan, transduser kapasitif telah diverifikasi berdasarkan ASTM D.1076-02 terhadap sampel larutan getah lateks oleh Laboratorium Penguji Balai Penelitian Teknologi Karet Bogor Sebelum digunakan, transduser kapasitif telah diverifikasi berdasarkan ASTM D.1076-02 terhadap sampel larutan getah lateks oleh Laboratorium Penguji Balai Penelitian Teknologi Karet Bogor. Penelitian yang dilakukan meliputi tahapan preparasi sampel, penyiapan sistem transduser kapasitif, pengujian sampel dan analisa data hasil pengujian.

Dalam pengukuran ini dilakukan preparasi larutan sodium hidroksida $(\mathrm{NaOH})$ menggunakan kristal $\mathrm{NaOH}$ pro analisis (PA). Kristal $\mathrm{NaOH}$ dilarutkan menggunakan pelarut air (aquades) dengan variasi konsentrasi larutan 10\% sampai 80\%, kemudian konsentrasi $\mathrm{NaOH} 80 \%$ digunakan sebagai referensi untuk pengkuran konsentrasi larutan $\mathrm{NaOH} 10 \%$ sampai $40 \%$.

Pada tahap penyiapan sistem transduser kapasitif mengikuti prosedur penggunaan alat sesuai manualbook "Gamaprolad versi 1.1". Kemudian untuk pengukuran konsentrasi larutan gula variasi konsentrasi, yang pertama dilakukan adalah menentukan tegangan bawah $\left(\mathbf{V}_{\mathbf{b}}\right)$, yaitu tabung sensornya diisi dengan larutan $\mathrm{NaOH} 80 \%$. Selanjutnya dipilih menu "Get V Bot" pada transduser kapasitif, kemudian tekan enter. Langkah kedua adalah untuk menentukan tegangan atas $\left(\mathbf{V}_{\mathbf{T}}\right)$, yaitu tabung sensornya diisi dengan air (aquades) kemudian dipilih menu "Get V Top" dan tekan enter. Setelah itu, larutan $\mathrm{NaOH}$ dengan variasi konsentrasi dapat diukur satu persatu menggunakan transduser kapasitif sehingga dari setiap konsentrasi larutan $\mathrm{NaOH}$ diperoleh data tegangan terukur (Vr). Dari data tegangan terukur tersebut akan diperoleh konsentrasi larutan terukur sesuai dengan persamaan (Anonim, 2010);

$$
\text { Konsentrasi }=\left|\frac{V_{r}-V_{T}}{V_{T}-V_{h}}\right| x 100 \%
$$

Untuk tampilan layar LCD sistem transduser kapasitif "Gamaprolad versi 1.1" ditunjukkan pada Gambar 1. 


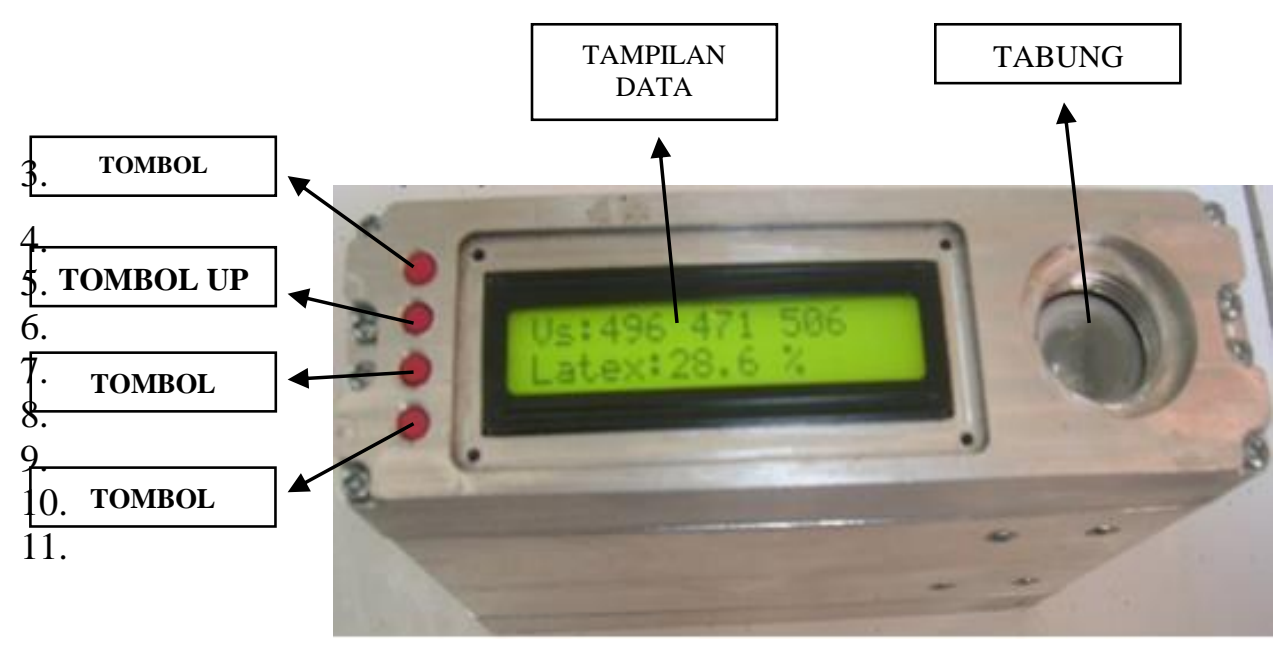

Gambar 1. Tampilan sistem transduser kapasitif 8- channel untuk pengukuran konsentrasi larutan (Anonim, 2010).

Data-data tegangan dan konsentrasi yang diperoleh melalui pengukuran untuk setiap konsentrasi larutan kemudian dilakukan analisis dengan analisis statistik atau dilakukan analisis metrologi yaitu dengan menentukan nilai rata-rata pengukuran, simpang baku sampai dengan budget ketidakpastiannya (uncertainty budget). Untuk penentuan simpang baku (standard deviasi) digunakan rumus;

$$
s=\sqrt{\frac{\sum_{i=1}^{n}\left(x_{i}-\bar{x}\right)^{2}}{(n-1)}}
$$

Dengan $\boldsymbol{s}$ merupakan simpang baku dan $\boldsymbol{n}$ merupakan banyak data pengukuran berulang atau jumlah pengulangan pengukuran. Kemudian penentuan standar ketidakpastian pengukuran (u) dapat ditentukan menggunakan rumus standar ketidakpastian dengan evaluasi tipe A yaitu;

$$
\boldsymbol{u}=\frac{s}{\sqrt{n}}
$$

Kemudian untuk penentuan ketidakpastian baku gabungan (combined uncertainty) dapat diperoleh dengan mengkuadratkan ketidakpastian lainnya yang berpengaruh dalam pengukuran tersebut, kemudian dijumlahkan dan diambil akar kuadrat totalnya;

$$
\text { Combined uncertainty }\left(u_{n}\right)=\sqrt{a^{2}+b^{2}+\ldots \text { etc. }}
$$

Setelah ditentukan standar ketidakpastian baku gabungan, maka akan diperoleh re-skala (penskalaan ulang) hasil pengukuran dimana ketidakpastian baku gabungan akan setara dengan "satu standar deviasi", sehingga diperlukan ketidakpastian yang dapat dinyatakan dengan tingkat kepercayaan tertentu seperti 95\%. Penskalaan ulang ini dapat dilakukan menggunakan faktor cakupan $\boldsymbol{k}$. Mengalikan ketidakpastian baku gabungan dengan sebuah faktor cakupan memberikan hasil yang disebut ketidakpastian bentangan (expanded uncertainty).

Keterangan;

$$
\boldsymbol{U}=\boldsymbol{k} \boldsymbol{u}_{\boldsymbol{c}}
$$

$$
\begin{aligned}
& \boldsymbol{U}=\text { ketidakpastian bentangan } \\
& \boldsymbol{u}_{\boldsymbol{c}}=\text { ketidakpastian baku gabungan }
\end{aligned}
$$

20 DOI: $\underline{10.25077 / j i f .10 .1 .17-27.2018}$ 
$\boldsymbol{k}=1$ untuk tingkat kepercayaan kira-kira 68 persen, $\boldsymbol{k}=2$ untuk tingkat kepercayaan 95\%, $\boldsymbol{k}=2.58$ untuk tingkat kepercayaan $99 \%$ dan $\boldsymbol{k}=3$ untuk tingkat kepercayaan $99.7 \%$.

Selanjutnya data hasil pengukuran ditampilkan dalam bentuk grafik menggunakan program Kaleidagraph sehingga menunjukkan track untuk masing-masing pengukuran konsentrasi larutan bahan. Masing-masing pengukuran konsentrasi larutan dipetakan dengan grafik tegangan terukurnya serta grafik konsentrasi larutan terukurnya. Dari grafik tegangan dan konsentrasi larutan ini akan diketahui perbedaan untuk masing-masing jenis larutan terukur yakni larutan $\mathrm{NaOH}$ variasi konsentrasi.

\section{HASIL DAN DISKUSI}

Sodium hidroksida $(\mathrm{NaOH})$ yang digunakan untuk membuat larutan dalam penelitian ini adalah kristal $\mathrm{NaOH}$ pro analisis yang dapat dijual ditoko-toko bahan kimia. Kristal $\mathrm{NaOH}$ yang telah ditimbang dengan berat tertentu sesuai kebutuhan konsentrasi larutan yang diinginkan, dilarutkan dengan pelarut air menggunakan magnetic stirrer yang berfungsi untuk menghancurkan kristalnya dan mempercepat reaksi pelarutan. Kemudian larutan Sodium hidroksida $(\mathrm{NaOH})$ dengan variasi konsentrasi dilakukan pengukuran konsentrasi menggunakan transduser kapasitif. Hasil pengukuran tersebut ditampilkan pada Tabel 1.

Hasil dari pengukuran berupa data tegangan tersebut kemudian dilakukan perhitungan untuk menentukan nilai tegangan rata-rata, deviasi standar dan ketidakpastiannya. Adapun deviasi standar dan ketidakpastian dari pengukuran larutan $\mathrm{NaOH}$ variasi konsentrasi dengan referensi $\mathrm{NaOH} 80 \%$ ditunjukkan pada Tabel 2.

Dari data Tabel 2, kemudian direpresentasikan dalam bentuk grafik hubungan antara konsentrasi larutan dengan tegangan terukur pada transduser kapasitif seperti yang ditunjukkan pada Gambar 2. Pada Gambar 2, tiga titik yang terlihar dalam grafik merupakan nilai rata-rata pengukuran berulang yang dilakukan sebanyak lima kali pengulangan untuk setiap titiknya 
Tabel 1. Hasil pengukuran larutan $\mathrm{NaOH}$ dengan referensi $\mathrm{NaOH} 80 \%$ menggunakan transduser kapasitif

\begin{tabular}{|c|c|c|c|c|}
\hline $\begin{array}{c}\text { Konsentrasi } \\
\text { Larutan NaOH (\%) }\end{array}$ & $\mathrm{Vt}(\mathrm{mV})$ & $\mathbf{V b}(\mathbf{m V})$ & $\begin{array}{c}\mathbf{V r} \\
(\mathbf{m V})\end{array}$ & $\begin{array}{c}\text { Konsentrasi } \\
\mathrm{NaOH} \text { terukur } \\
(\%)\end{array}$ \\
\hline \multirow{6}{*}{10} & 3740 & 3661 & 3734 & 7.6 \\
\hline & 3740 & 3661 & 3733 & 8.9 \\
\hline & 3740 & 3661 & 3732 & 10.1 \\
\hline & 3740 & 3661 & 3734 & 7.6 \\
\hline & 3740 & 3661 & 3735 & 6.3 \\
\hline & 3740 & 3661 & 3735 & 6.3 \\
\hline \multirow{7}{*}{20} & 3740 & 3661 & 3726 & 17.7 \\
\hline & 3740 & 3661 & 3727 & 16.4 \\
\hline & 3740 & 3661 & 3725 & 18.9 \\
\hline & 3740 & 3661 & 3726 & 17.7 \\
\hline & 3740 & 3661 & 3725 & 18.9 \\
\hline & 3740 & 3661 & 3728 & 15.2 \\
\hline & 3740 & 3661 & 3727 & 16.4 \\
\hline \multirow{6}{*}{40} & 3740 & 3661 & 3714 & 32.9 \\
\hline & 3740 & 3661 & 3715 & 31.6 \\
\hline & 3740 & 3661 & 3714 & 32.9 \\
\hline & 3740 & 3661 & 3712 & 35.4 \\
\hline & 3740 & 3661 & 3715 & 31.6 \\
\hline & 3740 & 3661 & 3713 & 34.2 \\
\hline
\end{tabular}

Tabel 2. Nilai ralat dan deviasi standar dari tegangan terukur larutan $\mathrm{NaOH}$ dengan referensi $\mathrm{NaOH} 80 \%$

\begin{tabular}{|c|c|c|c|}
\hline $\begin{array}{c}\text { Konsentrasi } \\
\text { larutan gula } \\
(\%)\end{array}$ & $\begin{array}{c}\text { Tegangan terukur } \\
\text { rata-rata }(\mathrm{mV})\end{array}$ & $\begin{array}{c}\text { Deviasi } \\
\text { standar }(\mathrm{mV})\end{array}$ & Ketidakpastian $(\mathrm{mV})$ \\
\hline 10 & 3733.8 & 1.2 & 0.5 \\
\hline 20 & 3726.3 & 1.1 & 0.4 \\
\hline 40 & 3713.8 & 1.2 & 0.5 \\
\hline
\end{tabular}




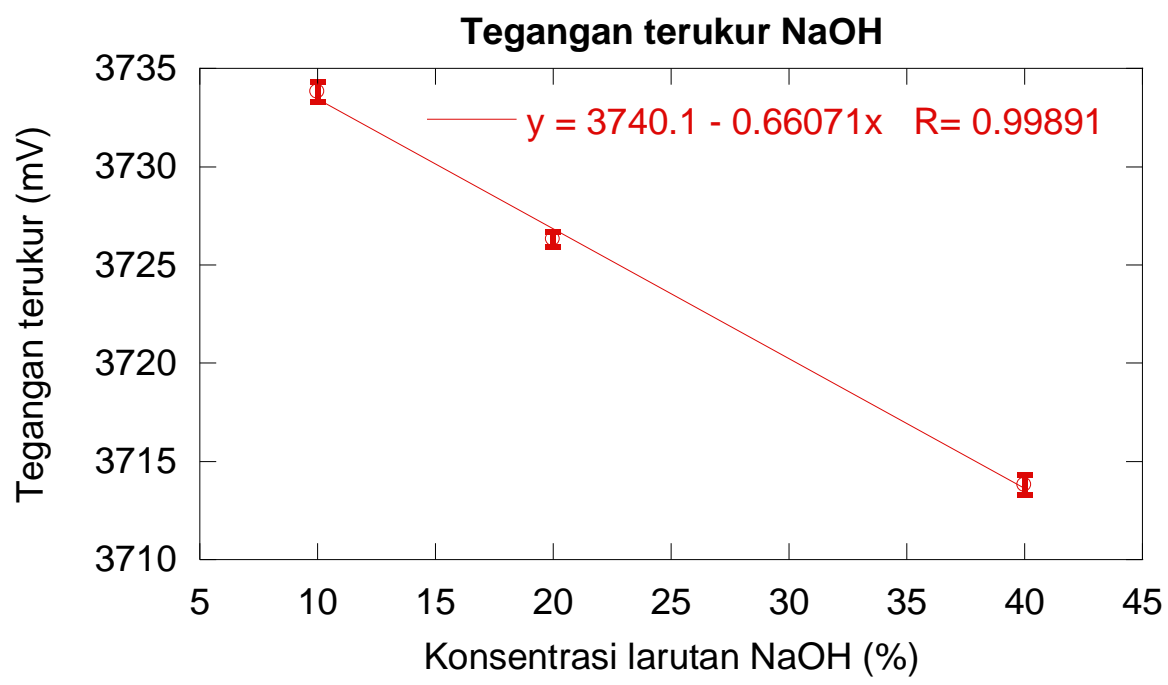

Gambar 2. Hasil pengukuran tegangan dari larutan $\mathrm{NaOH}$ variasi konsentrasi dengan referensi $\mathrm{NaOH} 80 \%$ menggunakan transduser kapasitif

Koofisien korelasi yang diperoleh dari pengukuran ini adalah sebesar 0,999 yang menunjukkan akurasi sebaran data yang diperoleh. Akan tetapi terlihat perbedaan yang signifikan pada nilai tegangan terukurnya yang hanya mengalami perubahan nilai pada rentang $25 \mathrm{mV}$ dan sangat berbeda sekali dengan data tegangan larutan gula yang memiliki rentang nilai tegangan sampai ratusan $\mathrm{mV}$. Hal ini menunjukkan perubahan konsentrasi larutan tidak terlalu dipengaruhi oleh tegangan keluaran instrumen. Daya hantar listrik atau konduktivitas molar elektrolit tidak tergantung pada konsentrasi larutan. Karena ion saling berinteraksi dengan kuat pada larutan elektrolit sehingga konduktivitas larutan tidak tepat sebanding dengan jumlah ion yang ada. Sehingga konduktivitas pada elektrolit kuat hanya sedikit berkurang dengan bertambahnya konsentrasi.

Kemudian dari harga mutlak data tegangan terukur ( $\mathbf{V r})$ dikurangi dengan tegangan atasnya $(\mathbf{V t})$ dibagi selisih tegangan atas $(\mathbf{V t})$ dengan tegangan bawah $(\mathbf{V b})$ dan dikalikan dengan $100 \%$ akan diperoleh konsentrasi terukur dari larutan $\mathrm{NaOH}$. Data konsentrasi yang diperoleh dari perubahan tegangan terukur tersebut kemudian dilakukan penghitungan ketidakpastian dan deviasi standarnya. Adapun rincian nilai ketidakpastian pengukuran (uncertainty) dan deviasi standar (standard deviation) dari ketiga titik pengukuran larutan $\mathrm{NaOH}$ dengan pengulangan pada masing-masing titik sebanyak lima kali ditunjukkan pada Tabel 3. 
Tabel 3. Ketidakpastian dan deviasi standar pengukuran dari larutan $\mathrm{NaOH}$ menggunakan transduser kapasitif Gamaprolad

\begin{tabular}{|c|c|c|c|}
\hline $\begin{array}{c}\text { Konsentrasi } \\
\text { Larutan NaOH } \\
(\%)\end{array}$ & $\begin{array}{c}\text { Konsentrasi } \\
\text { Terukur } \\
(\%)\end{array}$ & $\begin{array}{c}\text { Deviasi } \\
\text { standar (\%) }\end{array}$ & $\begin{array}{c}\text { Ketidakpastian } \\
(\%)\end{array}$ \\
\hline 10 & 7.8 & 2.8 & 1.2 \\
\hline 20 & 17.3 & 3.2 & 1.2 \\
\hline 40 & 33.1 & 7.7 & 3.0 \\
\hline
\end{tabular}

Dari Tabel 3, kemudian dapat direpresentasikan nilai konsentrasi terukur tersebut kedalam sebuah grafik yang ditunjukkan oleh Gambar 3 yang menggambarkan hubungan antara konsentrasi larutan gula terhadap konsentrasi larutan terukur pada transduser kapasitif. Selain data tegangan, juga diperoleh data konsentrasi dari perubahan tegangan terukur pada tampilan transduser kapasitif. Data tersebut kemudian dilakukan penghitungan ketidakpastian dan deviasi standarnya yang direpresentasikan kedalam grafik pada Gambar 3.

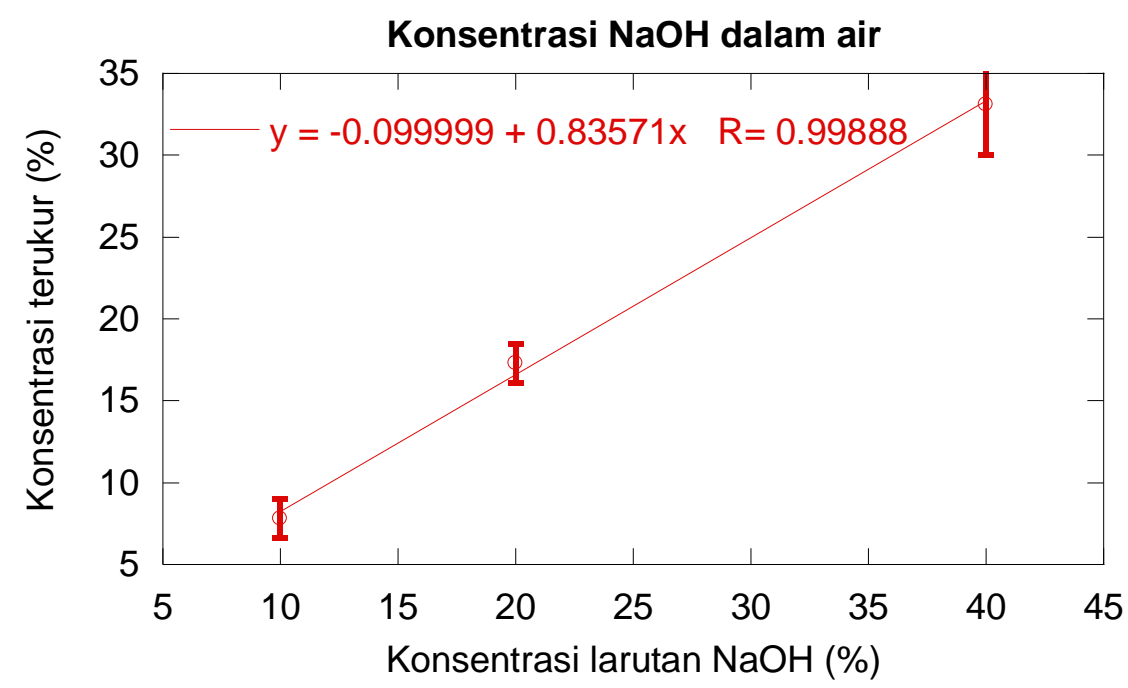

Gambar 3. Hasil pengukuran konsentrasi larutan $\mathrm{NaOH}$ dengan referensi $\mathrm{NaOH}$ $80 \%$ menggunakan transduser kapasitif

Pada Gambar 3 dan Tabel 3, terlihat bahwa dari tiga variasi konsentrasi yang dilakukan pengukuran, pada konsentrasi $40 \%$ panjang atau tinggi dari bendera (stated specification) lebih tinggi dari konsentrasi lainnya sehingga menimbulkan kecurigaan adanya data yang tidak relevan dari keenam data pengukurannya. Hal ini perlu dibuktikan dengan menggunakan kriteria Chauvenet agar dapat ditentukan ada tidaknya data yang akan dihilangkan sehingga sebaran data pengukurannya lebih baik yang ditunjukkan oleh nilai deviasi standar dan ketidakpastiannya yang semakin kecil. Kriteria Chauvenet dari pengukuran larutan $\mathrm{NaOH}$ dengan referensi $\mathrm{NaOH} 80 \%$ untuk konsentrasi terukur larutan $40 \%$ disajikan pada Tabel 4 berikut; 
Tabel 4. Penentuan nilai d/s dari data konsentrasi larutan $\mathrm{NaOH} 40 \%$ dengan referensi $\mathrm{NaOH} 80 \%$ menggunakan Chauvenet criterion

\begin{tabular}{|c|c|c|c|}
\hline No. & $\boldsymbol{x}_{\boldsymbol{i}}$ & $\boldsymbol{d}=\left|\boldsymbol{x}_{\boldsymbol{i}}-\overline{\boldsymbol{x}}\right|$ & $\boldsymbol{d} / \boldsymbol{s}$ \\
\hline 1 & 32.9 & 0.2 & 0.1 \\
\hline 2 & 31.6 & 1.5 & 1 \\
\hline 3 & 32.9 & 0.2 & 0.1 \\
\hline 4 & 35.4 & 2.3 & 1.5 \\
\hline 5 & 31.6 & 1.5 & 1 \\
\hline 6 & 34.2 & 1.1 & 0.7 \\
\hline
\end{tabular}

Dari kriteria Chauvenet yang ditampilkan pada tabel 4 , nila $d / s$ yang dihasilkan dari data pengukuran masih dibawah kriteria pembuangan atau penolakan data dengan jumlah pengulangan data sebanyak enam kali yaitu sebesar 1.73, sehingga tidak ada data yang memenuhi kriteria untuk dibuang dari kumpulan data pengukuran larutan $\mathrm{NaOH} 40 \%$ tersebut. Hal ini menunjukkan bahwa data yang diperoleh dalam pengukuran ini masih dalam rentang yang wajar dan bisa diterima serta dapat dipertanggung jawabkan. Sehingga nilai ketidakpastian yang digunakan dalam tampilan grafiknya dinilai wajar dan tetap sama dengan sebelumnya.

Hasil perhitungan budget ketidakpastian pengukuran untuk tiga titik pengukuran dengan pengulangan pada masing-masing titik sebanyak enam kali ditampilkan pada tabel 5 . Pada tabel 5, terlihat bahwa pada konsentrasi larutan $\mathrm{NaOH} 40 \%$ diperoleh nilai budget ketidakpastian yang lebih besar dari konsentrasi larutan $\mathrm{NaOH}$ lainnya yaitu dengan ketidakpastian bentangan (Expanded Uncertainty) sebesar 6,2 \% dengan jumlah pengulangan data pengukuran sebanyak 6 kali. Artinya nilai konsentrasi yang terukur masih bisa terkoreksi maksimum sebesar $6,2 \%$ dari nilai terukur hasil pembacaan instrumen. Dimana hasil ketidakpastian bentangan ini juga merupakan jumlah dari ketidakpastian-ketidakpastian lain atau ralat yang mempengaruhi nilai terukur dari sebuah pengukuran.

Hasil penghitungan budget ketidakpastian larutan $\mathrm{NaOH}$ untuk konsentrasi $\mathrm{NaOH} 10 \%$ diperoleh konsentrasi terukur sebesar $(2,8 \pm 2,4)$ persen, konsentrasi $20 \%$ diperoleh konsentrasi terukur $(6,0 \pm 3,6)$ persen dan konsentrasi $40 \%$ diperoleh konsentrasi terukur $(12,4 \pm 6,2)$ persen. Dari pengukuran ini, nilai budget ketidakpastian yang terbesar dari konsentrasi larutan $\mathrm{NaOH}$ yaitu sebesar 6,2 \% dengan jumlah pengulangan data pengukuran sebanyak 6 kali. Artinya nilai konsentrasi yang terukur masih bisa terkoreksi maksimum sebesar 6,2\% dari nilai terukur hasil pembacaan transduser kapasitif. 
Tabel 5. Model spreadsheet yang menunjukkan budget ketidakpastian pengukuran konsentrasi larutan $\mathrm{NaOH}$ dengan referensi $\mathrm{NaOH} 80 \%$

\begin{tabular}{|c|c|c|c|c|c|}
\hline Concentration & $\begin{array}{c}\text { Source of } \\
\text { uncertainty }\end{array}$ & $\begin{array}{c}\text { Value } \\
\pm\end{array}$ & $\begin{array}{l}\text { Probability } \\
\text { distribution }\end{array}$ & Divisor & $\begin{array}{c}\text { Standard } \\
\text { uncertainty }\end{array}$ \\
\hline \multirow[t]{4}{*}{$10 \%$} & $\begin{array}{l}\text { Resolution (size } \\
\text { of division) }\end{array}$ & $0,1 \%$ & Rectangular & $\sqrt{3}$ & $0,1 \%$ \\
\hline & $\begin{array}{l}\text { Standard } \\
\text { uncertainty of } \\
\text { mean } 6 \text { repeated } \\
\text { reading }\end{array}$ & $1,2 \%$ & Normal & 1 & $1,2 \%$ \\
\hline & $\begin{array}{l}\text { Combined } \\
\text { standard } \\
\text { uncertainty }\end{array}$ & & $\begin{array}{c}\text { Assumed } \\
\text { normal }\end{array}$ & & $1,2 \%$ \\
\hline & $\begin{array}{l}\text { Expanded } \\
\text { uncertainty }\end{array}$ & & $\begin{array}{c}\text { Assumed } \\
\text { normal }(\mathrm{k}=2)\end{array}$ & & $2,4 \%$ \\
\hline \multirow[t]{4}{*}{$20 \%$} & $\begin{array}{l}\text { Resolution (size } \\
\text { of division) }\end{array}$ & $0,1 \%$ & Rectangular & $\sqrt{3}$ & $0,1 \%$ \\
\hline & $\begin{array}{l}\text { Standard } \\
\text { uncertainty of } \\
\text { mean } 6 \text { repeated } \\
\text { reading }\end{array}$ & $1,2 \%$ & Normal & 1 & $1,2 \%$ \\
\hline & $\begin{array}{l}\text { Combined } \\
\text { standard } \\
\text { uncertainty }\end{array}$ & & $\begin{array}{c}\text { Assumed } \\
\text { normal }\end{array}$ & & $1,2 \%$ \\
\hline & $\begin{array}{l}\text { Expanded } \\
\text { uncertainty }\end{array}$ & & $\begin{array}{c}\text { Assumed } \\
\text { normal }(\mathrm{k}=2)\end{array}$ & & $2,4 \%$ \\
\hline \multirow[t]{4}{*}{$40 \%$} & $\begin{array}{l}\text { Resolution (size } \\
\text { of division) }\end{array}$ & $0,1 \%$ & Rectangular & $\sqrt{3}$ & $0,1 \%$ \\
\hline & $\begin{array}{l}\text { Standard } \\
\text { uncertainty of } \\
\text { mean } 6 \text { repeated } \\
\text { reading }\end{array}$ & $3,1 \%$ & Normal & 1 & $3,1 \%$ \\
\hline & $\begin{array}{l}\text { Combined } \\
\text { standard } \\
\text { uncertainty }\end{array}$ & & $\begin{array}{c}\text { Assumed } \\
\text { normal }\end{array}$ & & $3,1 \%$ \\
\hline & $\begin{array}{l}\text { Expanded } \\
\text { uncertainty }\end{array}$ & & $\begin{array}{c}\text { Assumed } \\
\text { normal }(\mathrm{k}=2)\end{array}$ & & $6,2 \%$ \\
\hline
\end{tabular}

Hasil ini menunjukkan bahwa konsentrasi larutan $\mathrm{NaOH}$ yang dilarutkan kedalam pelarut air sebenarnya cenderung untuk menghantarkan muatan listrik karena sifatnya yang merupakan basa kuat sekaligus sebagai larutan elektrolit kuat. Hal ini menunjukkan kharakteristik larutan $\mathrm{NaOH}$ yang bersifat basa, sama seperti basa lainnya misalnya $\mathrm{KOH}$. Bahan kimia basa seperti $\mathrm{NaOH}$ dan $\mathrm{KOH}$ ini sangat bagus digunakan sebagai bahan campuran pembuatan sabun dan detergen. Dimana detergen adalah senyawa bahan kimia yang bernama alkyl benzene sulfonat (ABS) yang direaksikan dengan natrium hidroksida $(\mathrm{NaOH})$. Bahan ABS diperoleh dari hasil pengolahan minyak bumi. Sabun dan detergen berfungsi sebagai pembersih karena memiliki dua sifat sekaligus yaitu sifat polar dan nonpolar. Air disebut sebagai larutan yang bersifat polar artinya larutan yang dapat bermuatan listrik, meskipun sangat lemah. Minyak bersifat non-polar artinya tidak dapat 
bermuatan listrik. Minyak yang bersifat non polar tidak dapat bercampur dengan air yang bersifat polar. Agar minyak dan air dapat bercampur maka digunakan sabun yang memiliki dua sifat, yaitu satu sisi bersifat non polar dan sisi lain bersifat polar. Air yang bersifat polar diikat oleh ujung sabun yang bersifat polar sedangkan minyak/lemak/kotoran organik yang bersifat non polar diikat oleh ujung sabun lainnya yang bersifat non polar juga. Salah satu bukti bahwa detergen bubuk terbuat dari campuran $\mathrm{NaOH}$ adalah ketika mencuci dengan detergen yang sedikit dilarutkan dengan air maka akan terasa panas pada tangan yang menunjukkan bahwa kristal-kristal $\mathrm{NaOH}$ melepaskan energi untuk melarut dan terikat dengan atom-atom hidrogen sehingga terkadang penggunaan detergen tidak jarang akan merusak kulit atau menyebabkan kulit mengelupas setelah mencuci.

Jadi, larutan $\mathrm{NaOH}$ merupakan larutan elektrolit yang cenderung menghantarkan arus listrik sehingga tidak mewakili bahan dielektrik. Sifat bahan ini terlihat pada grafik tegangannya yaitu pada konsentrasi larutan gula terlihat jelas perubahan tegangan yang terukur ketika diberi medan listrik sedangkan $\mathrm{NaOH}$ hanya sedikit terjadi perubahan terhadap respon tegangan ketika diberi medan listrik.

\section{KESIMPULAN}

Dari hasil penelitian pengukuran menggunakan transduser kapasitif, bahwa semakin besar $\%$ konsentrasi larutan uji maka tegangan terukur (dalam mV) semakin rendah. Kemudian, semakin tinggi nilai tegangan terukur (dalam $\mathrm{mV}$ ) dari suatu larutan bahan maka akan semakin rendah \% kadar bahan terukurnya (gula). Hasil penentuan nilai kadar bahan sodium hidroksida $(\mathrm{NaOH})$ variasi konsentrasi menggunakan transduser kapasitif secara metrologi; untuk referensi $\mathrm{NaOH} \mathrm{80 \%} \mathrm{diperoleh} \mathrm{ketidakpastian} \mathrm{kadar} \mathrm{terukur} \mathrm{terbesar}$ $6,2 \%$. Dengan demikian, transduser kapasitif ini mempunyai potensi yang cukup bagus sebagai alat portabel alternatif untuk mengukur konsentrasi larutan dengan cepat tanpa preparasi sampel

\section{DAFTAR PUSTAKA}

1. Anonim, 2010, Manualbook Instruksi Pengguna Gama Prolad Version 1.5, Yogyakarta, Tim LPPT Unit II UGM.

2. Eryolamda, Reny, 2010, Kajian Respons Frekuensi Tetapan Dielektrik Material Keramik Calcium Copper Titanate (CaCu3Ti4O12), Prosiding Pertemuan Ilmiah $X X V$ HFI Jateng \& DIY, Laboratorium Fisika Zat Padat, Jurusan Fisika FMIPA UGM.

3. Hidayatullah, Muhammad, 2017, Pengukuran Konsentrasi Larutan Gula Menggunakan Transduser Kapasitif, Jrnal Ilmu Fisika (JIF), 9 (2017), 43-56.

4. Horng, Shin, Chong, 2003, Hardware Development of Electrical Capacitance Tomography Applying AC-based Concept, Tesis, Universiti Teknologi Malaysia.

5. Rejikumar dan J.Philip, 2010, Estimation of dry rubber content in natural rubber latex by differential scanning calorimetry, Journal Thermal, Analysis and Calorimetry, Springer, 101 (2010), 1047-1050.

6. Sehah, Abdullah dan Zaroh Irayani, 2009, Pemanfaatan Teknik Lissajous untuk Mengetahui Korelasi antara Kandungan Air terhadap Sifat Dielektrik Tanah, Berkala Fisika, 12, 77-84. ISSN: 1410-9662

7. Utomo, Hadi, Priyo, 2011, Pengaruh Lama Penggerusan terhadap Konstanta Dielektrik, Kekerasan, dan Mikrostruktur Keramik Oksida SiO2-MgO, Skripsi, Universitas Negeri Malang. 